katolickiej i chociaż nie było powszechne, to przecież trwało, dostarczając źródła dowodów teologom i ożywienia pobożności wiernych.

Natomiast czasy nowsze mówią daleko więcej w tym względzie. Już w okresie Soboru Trydenckiego tłumaczenie maryjne Rodz. 3, 15 było dość powszechnie,jakkolwiek nie wyłącznie przyjęte ${ }^{16}$ ) i dzisiaj również tylko do wyjątków należą teologowie, którzy tego sensu nie uznają. Ta dość ogólna i wielowiekowa zgodność przedstawicieli nauki katolickiej jest dużo mówiąca i dostarcza wybiłnego potwierdzenia sensu maryjnego Rodz. 3, 15, opartego na tekście z kontekstem.

Co się tyczy naszega wyżej przedłożonego sposobu tłumaczenia: podwójnej realizacji tekstu, musimy zaznaczyć, że nie jest on nowy. Zarówno o Ewie jak o Marii w znaczeniu dosłownym rozumie tekst Rodz. 3, 15 już św. Ireneusz ${ }^{17}$ ), a potem św. Epifaniusz ${ }^{18}$ ). $\mathrm{Z}$ nowszych autorów idą za tym zdaniem (z różnymi odcieniami): A. Crampon, A. Arndt S. I., M. Hetzenauer O. M. Cap., Chr. Pesch S. I., De Ambroggi, I. Prado C. SS. R., A. Bea S. I., B. H. Merkelbach O. P., J. Trinidad, A. Rivera, A. Vaccari S. I., J. Coppens.

Lublin

O. STANISEAW STYŚ T. J.

\title{
AVE MARIA
}

Od dawnych wieków czci Kościół łaciński Matkę Najświętszą pozdrowieniem anielskim:

Ave (Maria), gratia plena,

Dominus tecum,

benedicta $t u$ in mulieribus

et benedictus fructus ventris tui.

Słowa te wzięte są z ewangelii św. Łukasza, z opisu $Z$ wiastowania, gdzie je wypowiada anioł Gabriel. Oto czytamy tam w rozdziale 1, 26-28:

„A w miesiqu szóstym wysłany został anioł Gabriel od Boga do miasta galilejskiego, które się zwało Nazaret, do panny zaręczonej

${ }^{16)}$ Por. T. Gallus S. I., Interpretatio mariologica Protoevangelii (Gen. 3, 15) tempore postpatristico usque ad Concilium Tridentinum. 1949.

17) Adv. haer. III, 23, 7: MG 7, 964; por. RTK 1 (1949) 25-32.

18) Adv. haer.I, 3, haer. 78, nn. 18-19: MG 42, 729; por. RTK 1 (1949) $102-106$. 
$z$ człowiekiem, który się nazywał Józef a pochodzil $z$ rodu Dawida, a imię panny bylo Maria. A wszedlszy do niej rzekt:

Badź pozdrowiona, laski pelna, Panz tobq“.

Niektóre rękopisy, tak łacińskie jak greckie, dodają do pozdrowienia anielskiego także słowa: Błogoslawionaś ty między niewiastami, lecz jest to niewątpliwie wtręt późniejszy. Dodano tu słowa, kilkanaście wierszy niżej spisane przez ewangelistę a wypowiedziane przez E1żbietę, gdy ją odwièđziła Matka Najświętsza (Łuk. 1, 41-42):

„A stato się, gdy uslyszala Elżbieta pozdrowienie Marii, ... napelniona została Duchem Swiętym i zawolala głosem wielkim:

Błogosławionaś ty między niewiastami

$i$ blogoslawion owoc żywota twojego".

Pozdrowienie anielskie przez nas odmawiane składa sie więc $\mathrm{z}$ dwuch tekstów ewangelicznych, $\mathrm{z}$ pozdrowienia anioła Gabriela i radosnego okrzyku Elżbiety, oraz z późniejszego dodatku moidlitewnego. Także imię Maria po Ave jest doldatkiem liturgicznym, wziętym z Łuk. 1, 30, gdzie anioł Gabriel nazywa Marię po imieniu: Nie bój się, Mario. To połączenie obu zacytowanych tekstów nasuwało się samo przez się i jest tylko dowodem rosnącej w Kościele czci Matki Najświętszej, nic dziwnego, że dostało się także powoli do tekstu biblijnego.

1.

Ustalenie dokładne tekstu pozdrowienia anielskiego nie sprawia egzegezie większych trudności, natomiast interpretacja poszczególnych słów podlega licznym wahaniom i w komentarzach znajdujemy rozmaite odmienne wyjaśnienia, a wskutek tego także w przekładach mamy coraz to inne próby oddania sensu oryginału. Szczególnie dużo trudnołści sprawia tak egzegetom jak dogmatykom wyłuszczenie treści pierwszych słów: Ave - gratia plena, a trudność stąd pochodzi, że nie znamy oryginalnego brzmienia słów anielskich, bo Eukasz nam tylko przekazał ich przekład grecki. Rzecz jest pewna, że anioł nie przemawiał po grecku, niewątpliwie użył języka semickiego, to znaczy, hebrajskiego lub aramejskiego. Ze źródeł historycznych wynika, że w Galilei wówczas język aramejski był w ogólnym użyciu, w tym języku porozumiewali się Maria i Józef, ale i język hebrajski był ogólowi żydów dość dobrze znaný. Wszakże w synagogach modlono się przeważnie po hebrajsku i czytano teksty biblijne w tym języku, co 
jest łatwo zrozumiałe, bo różniçe między obu językami są minimalne, mniejsze aniżeli między językiem polskim a czeskim. Uzasadniona przeto jest hipoteza, że anioł jako zwiastun Boży przemawiał świętym językiem proroków czyli po hebrajsku.

Zostawiając na uboczu mało znaczący spór, czy u Łukasza w rozdziale I i II suponować źródło aramejskie czy hebrajskie, stawiamy sobie pytanie, jak słowa wstępne pozdrowienia anielskiego brzmiały po hebrajsku. W oryginale greckim czytamy:

\section{XAIPE KEXAPITOMENH,}

a jak wiadomo, chaire było u Greków zwykłym, codziennym pozdrowieniem, którym się ludzie witali. Etymologicznie znaczy chaire "ciesz się" jednak z czasem zatraciło się właściwe znaczenie i rozkaźnik ten stał się zwykłą formułą grzecznościową. Łacińska Wulgata, zgodnie z tzw. Vetus latina, tj. najstarszym przekładem lacińskim, tłumaczy:

\section{HAVE, GRATIA PLENA}

czyli oddaje pozdrowienie greckie analogicznym pozdrowieniem łacińskim, bo Rzymianie witali sie słowem have(ave), havete(avete), co oznaczało etymologicznie: „bądź zdrów", "bądź dobrej myśli". To samo czyni Biblia syryjska, tzw. peszittha, bo oddaje słowa anielskie po swojemu:

\section{szelama lekhi}

co oznacza: pokój tobie. W Syrii bowiem, gdziekolwiek używano języka syryjskiego czy aramejskiego, pozdrawiano się wzajemnie takimi właśnie słowami, które nam także i Biblia przekazała jako zwykła formułę powitalną w świecie żydowskim. Dlatego wolno nam postawić hipoteze, że anioł zastosował się do zwyczajów lokalnych i powitał Marię słowami hebrajskimi:

\section{Szâlôm lâkh,}

tj. ,pokój tobie". Przy tym pamiętać należy, że oddawanie hebrajskiego szalom przez polskie słowo: "pokój” nie jest całkiem ścisłe, bo w rzeczowniku hebrajskim jest o wiele głębsza treść. Szalom oznacza razem: szczęście, pokój i błogosławieństwo, w ogóle stan, w którym człowiek zewnętrznie i wewnętrznie "dobrze, błogo się czuje", i takiego właśnie błogosławieństwa życzy anioł Marii. Także Pan Jezus używa tego pozdrowienia, np. po zmartwychwstaniu (Łuk. 24, 36) : Pax vobis - pokó $j$ wam, tak samo w scenach u św. Jana 20,$19 ; 21,26$. Czyżby słów, których używa Chrystus zmartwychwstały w stosunku do uczniów, nie mógł użyć anioł w stosunku do Marii? 
Lecz nasuwa się obecnie pewna trudność. Jeżeli słowa anielskie brzmiały szalom lakh, dlaczego Łukasz nie tłumaczy dosłownie: eirênê soi tj. pokój tobie, jak to czyni na innych miejscach? Ten właśnie mo ment spowodował najpierw Klostermanna ${ }^{1}$ ) a następnie O. Lyonneta ${ }^{2}$ j do wysunięcia nowej hipotezy, mianowicie, że słowo chaire należy dosłownie przetłumaczyć na język aramejski czy hebrajski i je uważać za wezwanie, by Maria się radowała. Gaude et laetare, virgo Maria to byłby sens powitania anielskiego. Zdaniem tych egzegetów anioł powiedział:

ranni (po hebr.) lub chadaj (po aram.).

Najdokładniej rzecz zbadał O. Lyonnet T. J. i zestawił obfity materiał filologiczny i patrystyczny. Wykazał, że Septuaginta nieraz przez chaire tłumaczy hebrajskie ranni, (od ranan), a dalej, że wzywanie do radości należy do stylu proroków, którzy wołają: Raduj się, córko syjońska (Soph 3,14) itp. Znany profesor Instytutu Biblijnego stanął tu w opozycji do takich autorów, jak biskup Schaefer, Bardenhewer, Jouon, Lagrange, Médebielle, Dausch, Ceuppens, ${ }^{3}$ ) którzy także głębiej kwestię rozpatrywali a doszli do przekonania, że raczej trzeba się liczyć z zwyczajami palestyńskimi i za podstawę dalszej interpretacji wziąć hebrajskie pozdrowienie: pokój tobie, które Łukasz oddał w duchu greckim przez chaire. A zresztą przypuszczać możemy, że przetłumaczenia słów hebrajskịch dokonali już przed Eukaszem pierwsi chrześcijanie, kiedy braciom, mówiącym tylko po grecku, przekazywali ważną wiadomość o Zwiastowaniu. Dalej wysunę przeciw $\mathrm{O}$. Lyonnetowi i to, że pierwsze dwa rozdziały ewangelii św. Eukasza mają duże pokrewieństwo $\mathrm{z}$ ewangelią św. Mateusza, bo są prawdopodobnie tak samo, jak pierwsza ewangelia, tłumaczone $z$ oryginału semickiego, a jeżeli właśnie u Mateusza hebr. pozdrowienie oddane jest przez chaire - tak np. wita Judasz Jezusa $(26,49)$ - tak samo anielskie szalom lakh mogło się zamienić na chaire.

A jeżeli bliżej kontekst rozpatrzymy, to nic nie przemawia za tym, by myśl o „radości" tutaj uwypuklić, sprzeciwia się temu nawet póź-

1) Das Lukasevangelium², Tübingen 1929, s. 13.

2) Por art. XAIPE KEXAPITOMENH w Biblica XX (1939), s. 131-141.

${ }^{3}$ ) Por. np. B a r d e $\mathrm{n}$ he wer, Mariae Verkündigung (Biblische Studien X, 4). Freiburg 1905, s. 82-100. - F. C e u p p en s O. P., De Mariologia Biblica. Torino 1948. 62-75. - A. S c h a e f e r. Die Gottesmutter in der Heiligen Schrift ${ }^{2}$ Münster i. W. 1900, s. 118-125. - P. J o ü o n, L'Annonciation, w Nouvelle Revue Théol. 1939, s. 795. 
niejsze wezwanie anioła: nie bój się, Mario, jak to już Jouon podkreślił. Zresztą łatwo było można usunąć wszelką wątpliwošć, jak należy zrozumieć słowo chaire, czy jako formułę powitalną cży też jako imperatyw: ciesz się, dodając do słowa chaire przysłówek bardzo = sphodra, jak to np. czyni prorok Zachariasz 9, 9: chaire sphodra, thygater Siôn = raduj się bardzo, córko syjońska. A jeżeli ewangelista tego nie uczynił, to chciał poprostu pozdrowieniu zostawić sens ogólny.

Pamiętajmy wreszcie i o tym, że semici lubują się $w$ paralelizmach, w powtarzaniu dwukrotnym tej samej lub podobnej myśli. Taki paralelizm wyraźnie spostrzegamy $\mathrm{w}$ pozdrowieniu anielskim:

a) pokój tobie,

b) Pan z toba,

czyli innymi słowy, także względy stylistyczne domagają się pozdrowienia hebrajskiego. A wzģląd ten jest wcale poważny, bo także słowa Elżbiety stanowią paralelizm:

a) błogosławionaś ty między niewiastami,

b) błogosławiony owoc żywota twojego.

W obu wypadkach występuje paralelizm syntetyczny, myśl pierwszego członu jest pogłębiona $\mathrm{i}$ uzupełniona $\mathrm{w}$ drugim członie. Przyjmując hipotezę $\mathrm{O}$. Lyonneta, rezygnujemy $\mathrm{z}$ paralelizmu, który bądź co bądź dodaje dużo piękna literackiego słowom anielskim.

Wszystkie te momenty razem wzięte przemawiaja za tym, że Łukaszowe chaire jest przekładem oryginalnego szalom lakh.

2.

Ważniejsze od pierwszego słowa, wypowiedzianego przez anioła, jest słowo drugie KEXAPITOMENH, bo na nim buduje dogmatyka ważne argumenty. Znów się pytamy, jak ono mogło brzmieć w języku hebrajskim czy aramejskim. Najczęściej ${ }^{4}$ ) tłumaczono je dotąd na 'eszeth chên, tj. „kobieta wdzięku, łaski" czyli "kobieta pełna wdzięku, łaskawości, łaski", R es ch h) proponuje hasîdah tj. dobra, pobożna. $\mathrm{Na}$ uzasadnienie przekładu: "kobieta (pełna) wdzięku" powołują się autorzy na księgę Jezusạ Siracha, w której greckiemu kecharitomenê odpowiada hebrajskie 'eszeth chên $(9,8)$ a gdzie mędrzec przestrzega

4) Por. np. Nowy Testament po hebr. w przekładzie Fr. Delit z s c h a, Lipsk 1892.

5) Por. A. R e s c h, Das Kindheitsevangelium nach Lucas und Matthaeus, Leipzig 1897, s. 206. 
czytelnika, by "oko zakrywał przed niewiastą piękną". Tu więc oznacza chên wdzięk zewnętrzny, co jednak nie odpowiada absolutnie tekstowi u Łulkasza. Owszem chên może oznaczać wdzięk zewnętrzny; chên odnosi się także do piękna zewnętrznega, tak samo jak greckie charis, ale zależnie od okoliczności rzeczownik ten oznacza równieź zalety wewnętrzne, właściwości duszy, a to już więcej harmonizuje $z$ duchem ewangelii św. Eukasza. Tutaj jednak i to nie wystarcza.

Pamiętajmy o tym, że Eukasz jest uczniem św. Pawła, u którego słowo charis $=$ chên już wyraźnie występuje na oznaczenie pewnvch nadprzyrodzonych kwalifikacji duszy czyli, jak dzisiaj mówimy, na oznaczenie łaski nadprzyrodzonej. Św. Eukasz, używając wyrazu kecharitomenê, nie mógł go w tekście teologicznym użyć w innym znaczeniú aniżeli w tym, w jakim go używał Apostoł Narodów. Czasownik charitoô, zachadzący w liście dio Efezjan 1, 6, wyraża myśl, że Bóg nas wyposażył w łaskę nadprzyrodzona, w łaskę adopcji Bożej, dzieki której stajemy się „dziećmi Boźymi". Jeżeli więc Łukasz nazywa Marię kecharitomenê, to zaznacza, że Maria jest wyposażona w laskę nadprzyrodzoną, a szczególnie w łaskę adopcji Bożej, która mieści w sobie pełnię wszelkich innych łask. Możliwe, że przed Lukaszem nie wszyscy rozumieli głębię pozdrowienia anielskiego, ale ewangelista pod wpływem Pawła i pod natchnienem Ducha św, dotarł do właściwego sensu słów Bożych, przez anioła światu zwiastowanych.

Za mało w ogóle dotąd podkreślano wielkie podobieństwo między "Ave Maria" a listem do Efezjan, w którym pojęcie „łaski" doskonale jest rozwinięte. Oto odnośny ustęp $(1,3-6)$ :

Blogosławiony Bóg i Ojciec naszego Pana Jezusa Chrystusa, który $w$ Chrystusie nas pobłogosławił wszelkịm błogoslawieństwem duchowym $w$ niebiesiech, jak i nas w Nim wybrał przed stworzeniem świata, abyśmy byli święci $i$ nieskalani $w$ jego oczach.

Oto $z$ miłości, z upodobania swej woli, przez Jezusa Chrystusa nas na swe dzieci przeznaczy?, aby wsławić wspaniałość Swej łaski, która nas łaskawie obdarzyl ${ }^{6}$ ) przez ukochanego Syna Swego. Przez Jego krew w Nim odkupienie mamy, odpuszczenie grzechów dzięki bogactwu Jego łaski, która najobficiej zlat na nas...

в) Tu mamy to samo słowo: ,echaritôsen“. 
W/szystkie myśli tych wierszy Pawłowych musimy zastosować do Marii, pierwszej chrześcijanki w pełnym tego słowa znaczeniu, i wszystkie one mieszczą się w słowie anioła: Kecharitomenê. Dlatego też tłumaczenie Vetus latina, pochodzące $z$ II wieku po Chr. a przejęte przez Wulgate i przez liturgię Kościoła: "gratia plena" - „łaski pełna", jest ścisłe i dobrze uzasadnione ${ }^{7}$ ). A dalszy stąd wniosek, że - jeżeli Maria w chwili Zwiastowania posiada łaskę adopcji, którą chrześcijanin otrzymuje przez chrzest - anioł ja pozdrawia jako osobę, której dusza już oczyszczona jest od grzechu pierworodnego, która wskutek tej adopcji posiada "pełnię lask nadprzyrodzonych", wyliczonych przez św. Pawła. Wiersz ten jest w tej formie - a nie innej - ścisłym argumentem na dogmat Niepokalanego Poczęcia N. M. P. Dodać należy $\mathrm{i}$ ten moment, po raz pierwszy podkreślony przez Łukasza $z$ Brügge (um. 1619), że imiesłów kecharitomenê zastępuje imię; anioł nie wymienia imienia Marii, lecz nazywa ją "pełną łask" - że więc pełnia łask jest tak ściśle $\mathrm{z}$ nią złączona, jak imię z osobą. KEXAPITOMENH to jakoby drugie imie Marii.

Poznawszy treść właściwa słowa anielskiego, jeszcze warto się nad tym zaștanowić, czy proponowany przekład na język hebrajski: 'eszeth chên jest słuszny. Ponieważ frazes ten odnosi się zwykle do wdzięku zewnętrznego, jest on mniej odpowiedni. Można by go zatrzymać, wkładając w chên pojęcie piękna duszy jak wyżej wspomniano, ale lepiej jednak użyć tu zwrotu odpowiedniejszego, mianowicie:

ba'alath chên,

tj. dosłownie: Pani (właścicielka) łaski (nadprzyrodzonej). W późniejszej hebrajszczyźnie ba'al i ba'alath + rzeczownik zastępuja przymiotniki i ściślejszą wyrażają łączność danej osoby z owym przymiotem. Będzie to w naszym wypadku zgodne z myślą Łukaszową, który jaknajściślej łączy „łaskę" z osobą Najświętszej Panienki.

3.

DOMINUS TECUM $=$ Pan $z$ toba, to zwrot hebrajski brzmiący w tym języku:

Jahwe 'imkhâ względnie immâkh

Tak np. pozdrowił Booz żniwiarzy na polu betleemskim, jak to opisuje księga Rut $(2,4)$. Z biegiem czasu pozdrowienie to wychodzi z użycia

$\left.{ }^{7}\right)$ W peszittha czytamy tak samo: „maliath tajbutha“ = pełna łaski. Por. wyd. Mosul 1898, s. 320. 
a miejsce jego zajmuje formuła: "pokój tobie". Prawdopodobną przyczyną tej zmiany był wzgląd na świętość imienia "Jahwe". Albowiem powstał zwyczaj, by imienia tego nie wymawiać w życiu prywatnym, lecz tylko $\mathrm{w}$ modlitwie $\mathrm{i}$ w świątyni, i dlatego dano pierwszeństwo pozdrowieniu nie zawierającemu tego imienia. Wyjątkowo tylko i $\mathrm{w}$ wielkich chwilach posługiwano się dawną formuła, o czym dokładnie pisze ks. $\mathrm{Hol} z \mathrm{~m}$ e is ter $\mathrm{w}$ artykule pt. Dominus tecum ${ }^{8}$ ). Niewątpliwie także użycie słów: Jahwe 'immakh - właśnie dlatego, że było mniej używane i zawierało imię Boże, którego oprócz kapłanów w świątyni nikomu już wówczas nie było wolno wymawiać - wywarło na Marii głębokie wrażenie i stanowiło jeden $\mathrm{z}$ powodów, dla których przelękła się słów anielskich (Łuk. 1, 29).

Z chwilą Zwiastowania rozpoczyna się era Nowego Zakonu. Nic dziwnego, że prastare pozdrowienie, wtedy przez anioła użyte, miało się w tej nowej epoce świata znowu stać formułą świętą. Dominus tecum i Dominus vobiscum to nasze codzienne pozdrowienie liturgiczne ${ }^{9}$ ). Użył go św. Paweł w II liście do Tesaloniczan 3, 16: Dominus (sit) cum omnibus vobis - Pan niech będzie z wami wszystkimi", wyrażając życzenie, by Pan się nimi stale opiekował i w duszach ich mieszkał. Słusznie Wulgata uzupełnia sit, którego nie ma w tekście greckim. Tę samą formułę, chociaż w nieco zmienionej szacie, umieszcza Apostoł w zakończeniu II listu do Koryntian $(13,11):$ Deus pacis et dilecttonis erit vobiscum - Bóg miłości i pokoju będzie z wami, ale jako orzeczenie a nie jako życzenie. Wiersz ten przypomina nam żywo pozdrowienie anielskie Dominus tecum, będące również orzeczeniem a nie życzeniem, to jest stwierdzeniem, że Bóg Jahwe jest $z$ Marią złączony w szczególny sposób, że opiekuje się nią, że mieszka w niej mistycznie napełniając jej duszę miłością nadprzyrodzoną i pokojem niebiańskim. Można by oczywiście słowo anielskie gramatycznie uważać za życzenie i uzupełnić sit a nie est, lecz sens wyżej rozprowadzony słowa kecharitomenê temu się sprzeciwia.

Dalsze słowa pozdrowienia maryjnego juź nie domagają się dokładniejszych objaśnień, chyba to powinniśmy sobie uświadomić, że

8) W miesięczniku Verbum Domini XXIII (1943), 260 n.

$\left.{ }^{9}\right)$ Por. Hozakowski, Wykład mszy św., Poznań 1914, s. 34 n.; Lexikon für Theologie und Kirche III kol. 398: Dictionnaire d'Archéol. et Lit. IV c. 1387 n. Właściwą formułą bylo Dominus robiscum, później wprowadzono na niektóre większe święta Pax vobis. 
zwrot: blogosławionaś ty między niewiastami jest hebraizmem, zastępującym superlatyw, ktörego język hebrajski nie posiada. Wiersz ten należy parafrazować: "najwięcej wśród niewiast ublogosławiona dziewico", "najszczęśliwsza niewiasto".

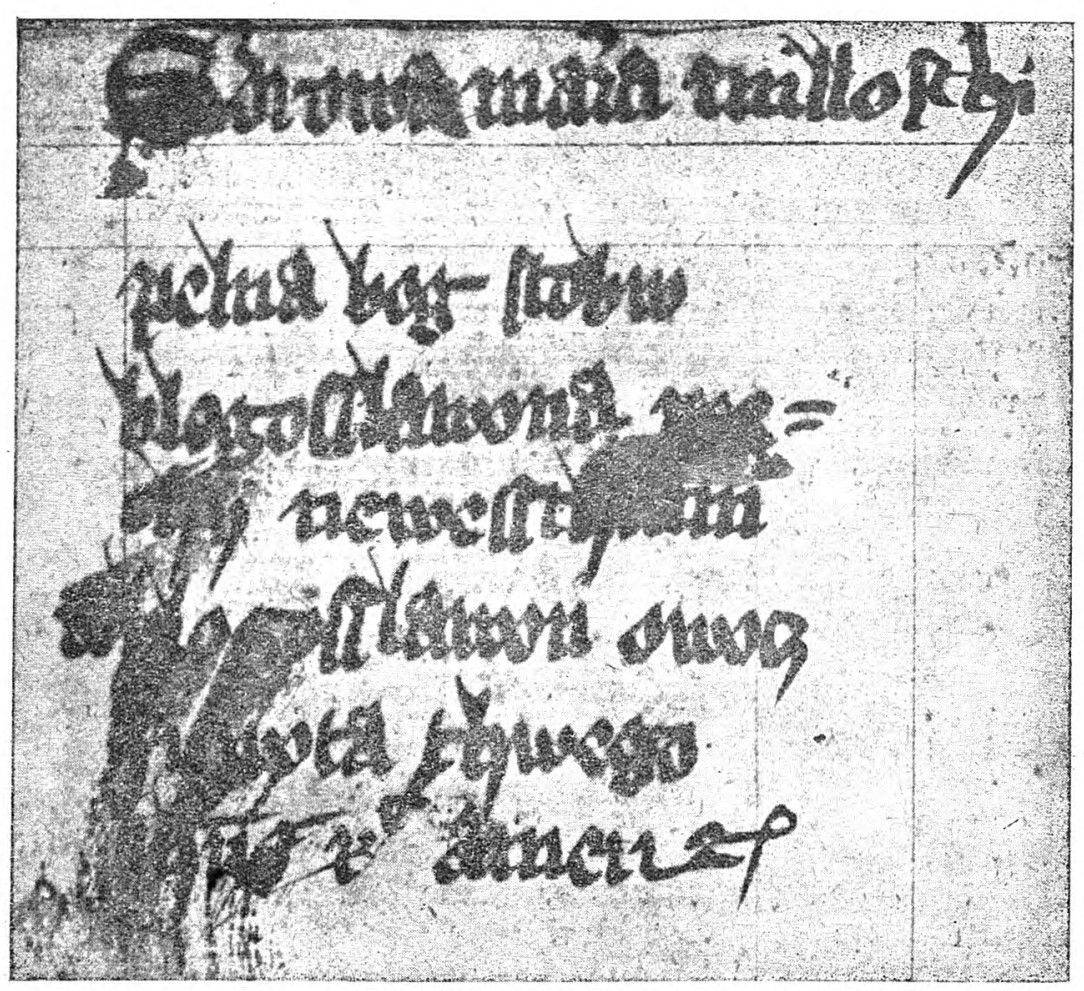

Najstarszy tekst polski Pozdrowienia Anielskiego z rękopisu Bibl. JagielI. Nr 825

Stosownie do wywodów wyżej podanych brzmiałoby pozdrowienie maryjne po hebrajsku:

\author{
szâlôm lâkh, ba'alath chên, \\ jahwe 'immâkh \\ berûkhath benâszîm \\ ubârûkh perî bitnêkh.
}


4.

Na zakończenie zestawmy niektóre ważniejsze przekłady pozdrowienia anielskiego.

Najstarszy tekst polski Ave Maria znajduje się w rękopisie Biblioteki Jagiellońskiej w Krakowie nr 825, pochodzącym z r. 1407. Brzmi on ${ }^{13}$ ):

Zdrowa Maria, miłości pełna, Bóg z toba,

błogosławiona między niewiastami

a blogosławion owoc żywota twego...

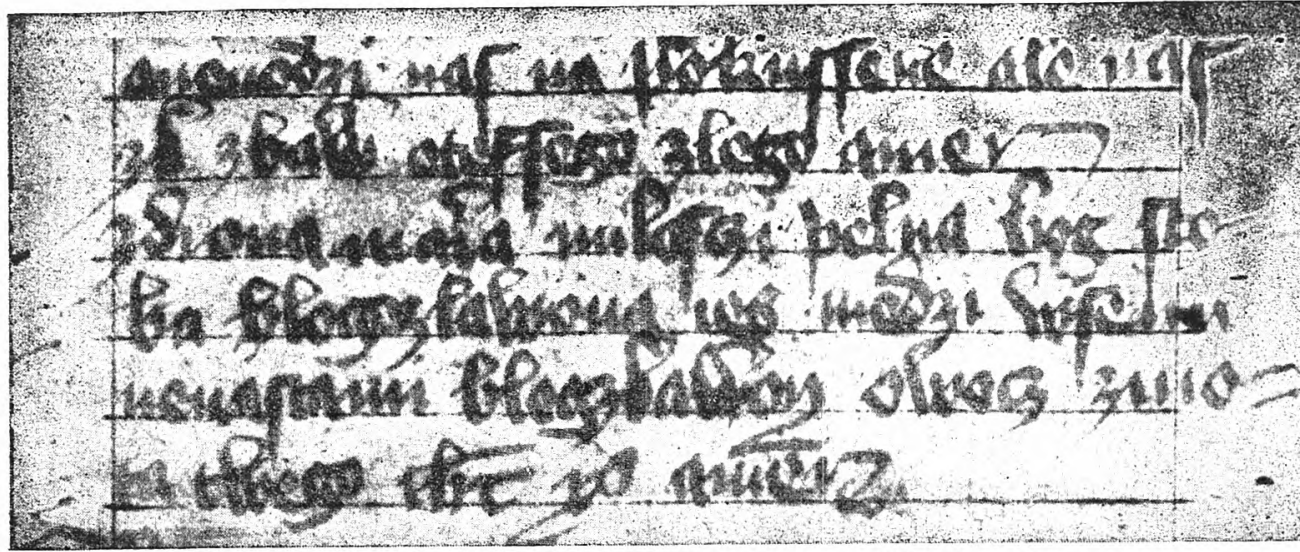

„Ave Maria” z rękopisu Bibl. Jagiellońskiej Nr 1681.

Podobnie brzmi tekst nieco późniejszy (rękopis Biblioteki Jagiellońskiej nr 1681).

Zdrowa Maria, miłości pelna, Bóg $z$ toba, błogosławiona jeś między wszemi niewiastami, błogosławion owoc żywota twego...

Tekst drukowany z r. 1475 takie ma brzmienie:

Zdrowa Maria, milości pelna, Bóg z toba,

błogoslawionaś ty między niewiastami,

blogosławiony owoc (plod) brzucha twego świętego...

Główna różnica między tekstem dzisiejszym a dawnym to słowa miłości pelnna - Bóg z tobq, zamiast laski pełna - Pan z tobq. Rzeczowo nie ma tu różnicy, bo słowo miłość oznaczało w staropolskim

13) Por. W i e r c z y ń s k i, Wybór tekstów staropolskich, Warszawa 1950, str. 49-51, gdzie teksty podane są $w$ oryginalnym staropolskim brzmieniu. Także Ł o ś, Początki piśmiennictwa polskieg.o, ${ }^{2}$ Lwów 1922, s. 201 n., je podaje. 
także laskę. W języku czeskim jeszcze dzisiaj milest oznacza łaskę a w pozdrowieniu anielskim mówi się zdrava bud, milosti plna. W rękopisie biblioteki Czartoryskich nr 3729, z końca XV wieku, późniejsza ręka dopisała na str. 383 nad słowem miłości - łaski, a nad Bóg - Pan. (Por. rycinę na str. 113).

Najstarszy tekst, podający przekład dzisiaj używany, znajduje się, o ile mi wiadomo, w rękopisie nr 1116 Biblioteki Ord. Zamoyskich $\mathrm{w}$ Warszawie, pochodzącym $\mathrm{z}$ końca $\mathrm{XV}$ wieku ${ }^{14}$ ):

Zdrowaś, łaski pełna, Pan z toba,

błogosławiona ty między niewiastami

$i$ blogosławion owoc żywota twego.

W Biblii Leopolity z r. 1568 mamy to samo tłumaczenie:

Zdrowaś, laski pełna...

Ks. Wujek zmienia przekład na:

Badż pozdrowiona, Zaski pełna...

i zachowuje go we wszystkich 3 wydaniach (z r. 1593, 1594 i 1599).

Biblie innowierców przyjęły przekład Seklucjana z r. 1551:

Badż pozdrowiona, $z$ łaski umiłowana...

bo znajdujemy go tak w Biblii Brzeskiej z r. 1563 jak w Biblii Szy. mona Budnego z r. 1574. Dopiero Biblia Gdańska z r. 1632 zmienia tekst na:

Badź pozdrowiona, łaskq udarowana.

Forma czasami spotykana: „łaskiś pełna" jest błędna, bo nie uzasadniona tekstem biblijnym.

$\mathrm{Z}$ francuskich przekładów wymienię $\mathrm{C} \mathrm{r}$ a $\mathrm{m}$ p on a:

Salut, pleine de grâce,

le Seigneur est avec vous...

Ten sam tekst ma Osty (w wydaniu z r. 1949). G a u me pisze: je vous salue, pleine de grâce, a protestant $\mathrm{S}$ e go nd parafrazuje: je te salue, toi à qui une grâce a été faite, le Seigneur est avec toi.

Włoski przekład O. Sales'a O. P. ma:

Dio ti salvi, plena di grazia,

il Signore è teco...

14) Por. J a in Ja nów, Zespół ewangeliczny Biblioteki Ord. Zamojskich nr. 1116, Warszawa 1928, str. 16 i_17. 
Autorzy niemieccy rozmaicie tłumaczą. Tradycyjny przekład brzmi (w Biblii Allioli'ego):

$$
\begin{aligned}
& \text { Gegrüsst seist du, voll der Gnaden, } \\
& \text { der Herr ist mit dir. }
\end{aligned}
$$

Nowsi piszą: Gegrüsset seist du, Gnadenvolle... (Laienbibel z r. 1938); Heil dir, Begnadete... (Dausch, Weiss); Sei gegrüsst, du Begnadigte... (Schachter). Biblia Lutra ma: Geǵrüsst seist du, Holdselige, ale może najlepszy i najprostszy przekład znajduje się w Nowym Testamencie ks. Röscha O. M. Cap.:

Sei gegriüsst, du Gnadenvolle.

Kilka zaledwie słów liczy pozdrowienie anielskie a ile nastręcza problemów nie rozwiązanych definitywnie, ile zawiera myśli pięknych i głłębokich! Średniowiecze bardzo pokochało słowa Łukasza i nieprzeliczona ilość teologóo je komentowała na swój sposób. Nie uznajemy dzisiaj ich metody eǵzegetycznej, ale nie możemy nie podziwiać ich umiłowania powitania Gabrielowego, które się niebawem stać miało modlitwą obok Chrystusowego "Ojcze nasz" przez wszystkich najwięcej ceniona. Tle naiwności, ale $z$ drugiej strony ile ciepła mistycznego tkwi w bardzo kiedyś rozpowszechnionej etymologii słowa Ave, że składa się z litery $a=a b$ (precz) i wykrzyknika vae (ve) = biada, by zaznaczyć, że przez anielskie ave zostało wszelkie zło (vae) ze świata usunięte ${ }^{10}$ ).

Podobna myśl tkwi w grze słów Ave - Eva, wskazującej na to, że co Eva zepsuła, została naprawione przez odwrócenie jej imienia czyli przez anielskie Ave. W hymnie Ave Maris Stella ten moment został wyzyskany w wierszu:

Sumens illud Ave

Gabrielis ore,

funda nos in pace, mutans Evae nomen.

O Mario, słowem Ave

uczczona przez anioła, spuść spokój, zmień los Ewy, tułaczów rzesza woła.

10) Por. B a rden hewer, Mariae Verkündigung s. 94. 
Szczeście to wiellie, żo słnwa te nam sie zachowały. Jeden święty Łukasz je nam przekazał, jemu je zawdzięczamy, a wciągnął je do swej ewangelii dlatego, że był głębokim czcicielem Matki Bożej, a poza tym człowiekiem, odczuwającym piękno religii Chrystusowej.

Piękno pozdrowienia anielskiego odczuła w głłębi swej duszy poetka polska Konstancia Benisławska (1747-1806). Ogłosiła przemiłą parafrazę modlitwy „Zdrowaś Maryja" $\left.{ }^{11}\right)$. W 9 pieśniach rozprowadza myśli pozdrowienia anielskiego, a że doceniała ich znaczenie, o tym świadczą pierwsze dwie strofy wstępne:

Darmo się silić! by kto wszystkie myśli

Zbił wszystkich Mędrców, żaden nie wymyśli

Wdzięczniejszej piosnki, żaden żadną miarą

Od Posła niebios nad „Zdrowaśc pieśń starą.

Ta pieśń szczęśliwie, szczęśliwa Maryjo,

Nowa zaczęla nam Ewangeliạ:

Ta pieśń godności Twej odmyka wrota

Ta pieśń początkiem naszego żywota.

Równie silnie odczuł piękno tej modlitwy penitencjarz i dyrygent krakowski z końca XVII wieku ks. Grzegorz Gorczyński. Jego utwór muzyczny na temat Ave Maria jest dziełem o wielkiej wartości artystycznej a dowodem, jak bardzo dusza polska pozdrowienie maryjne ceniła i w jego treść wnikała ${ }^{12}$ ).

\section{KS. ALERSY KLAWEK}

11) Wydane w Wilnie 1766. Por. T. Jo de $ł \mathrm{ka}$, Polska poezja maryjna, Niepokalanów 1949, s. 107. - Por. też Ave Maria ks. Karola Antoniewicza, tamże s. 163.

${ }^{12}$ ) Por. Ks. Józef Surzyński, Matka Boska w muzyce polskiej, w: Księdze pamiątkowej maryjańskiej I (Lwów 1905), s. 161-181. O Ave Maria Gorczyńskiego pisze autor (s. 174), że „mimo swego zawiłego opracowania kontrapunktycznego brzmi wspaniale". Tam także wyliczono liczne inne interpretacje muzyczne Ave Maria, skomponowane przez autorów polskich. 